\title{
THE PUBLIC OPENNESS PRINCIPLE IN GOVERMENT AGREEMENT
}

\author{
Indah Cahyani \\ Departement of Administrative Law, Universitas \\ Trunojoyo Madura \\ Madura, Indonesia
}

Abstract- The openness principle is a principle in The General Good Goverment Principles, on the other hand the agreement is an engagement that is subject to private law. The intersection between public law and private law in a legal act is a legal event that has two legal characters at once. The character of public law is characterized by the interference of government to the civil, another characteristic is the need for legality while the character of private law is the autonomy of the parties. Public Service Law article 5 clouse (3) letter c dan clouse (4) letter $c$ explains that, the scope of public services including public service provision that procurement, distribution or provision of services does not come from the State Budget or Regional Budget Or a business entity whose capital of incorporation is partly or wholly derived from the property of the State and / or the separated regional wealth, but its availability becomes a State mission laid down in legislation. From the description of the two verses explained that the private sector in conducting its business activities during what is the business activity is the provision of services and goods that become public needs, it can be said that private or private legal entities perform the functions of the State. Different characteristics between public law and private law related to private public relations in the provision of public services is a potential conflict problem in the future. This paper attempt to analyze the relationship between the openness principles and the law principles of agreemments, as well as its implementation in government agreements.
Key words: Openness Principle, Government Countract.

\section{INTRODUCTION}

The state in public services is often a meeting between the legal agreement principles and good government principles as the subject of public law. As the subject of public law, the government is subject to and bound by the principles of public law such as, the principle of legal certainty, the orderly principle of state administration, the principle of openness, the principle of proportionality, the principle of professionalism, and the principle of accountability.

In the books of the Law of State Administration, it is possible that the government as the subject of public law performs both private acts and public acts, it is explained that the government's actions are divided into two, namely material and legal action, legal action is divided into two, namely public legal action and action private law, and so on up to the character of legal norms within government legal instruments.

In the perspective of legal theory, throughout the history of legal development there have been various opinions regarding the relationship of private law (civil) and public law. According to the literature in the Netherlands the first to occupy this issue was Lori's mentor, in his dissertation of 1887, which essentially emphasized that the vertical relationships, superiors and subordinates, between the government and the citizens were subject to the provisions of public law, citizens themselves (horizontal relationship), it is governed by private law. 
Here Loef is still purely based on the doctrine of the sovereignty of the State, where in his opinion the State (government) is always acting according to public law. Even if such an action is committed by an ordinary person it will be subject to civil law. Thus all government actions that are legal property (vermogensrechtelijk) are always considered as acts according to public law (publiekrechteijk). Therefore civil judges are not authorized to examine disputes concerning such governmental legal actions.

Hammaker in 1894, argued that public law is not actually a law, but only a formulation in the law concerning the tasks and means used by the public is the law made by the legislator (wetgeversrecht). Because outside the law there is also no place for public law. While the private law is derived from a general legal consciousness, because it is superior to government and law. Hammaker's opinion is referred to as the teaching of "primaat van het privaatrecht".Meanwhile, H. Krabbe, argues that private law is a common law since ancient times. With the doctrine of the rule of law this means the government is subject to the common law. Krabbe's opinion stems from the idea of the rule of law which for the actions of the government is subject to this general law. Until now the doctrine of the common law (het gemenerechtsleer) is still a doctrine that is considered a general opinion. Besides, Kranenburg rejected Hammaker's opinion by saying that the rules of public law are also rooted in the awareness of the common law (society). Kranenburg then concludes that there are no distinct elements of distinction between the two areas of law. Meanwhile, according to Praag public law is applicable to the actions of the government as a ruler, while private law is a law applicable to other legal relationships. While Romijn (Administratiefrecht, Hand en Leerboek, 1934), who followed the opinion of Praag, said that the law of governance applies to the contact between the government and the ruled, while the private law regulates the legal relationship among fellow citizens, this is preferred to apply and the law is not the same as private law. Vegting also argues that private law is a common law, he acknowledges that the similarities between the two laws affect one another.
According to Immanuel Kant, in his freedom and autonomy, each individual tends to fight for his independence. But it is very possible that the exercise of one's independence can harm others. To avoid such losses, it takes the law. Law is the requirement of every free and autonomous being who wants or will not live together. According to Kant, the law must be free from pragmatic considerations based on sensory experience such as good taste, liking, feeling of profit, etc., so the law must be imperative and apply heteronomically.

Meanwhile, Jacques Rousseau built his theory of the law from the basic question, why did man originally live in a state of nature, free freedom, willing to become a person 'shackled' by the rules ?, because the law is public and therefore objective. The next question is, why is the law public and objective? Because the nature of the law is:

1) Volonte generale

2) Voltare de corps

3) Voltare de tortuous

4) Voltare particuliere 1

As a manifestation of volonte generale, law serves as an order that protects common interests as well as personal interests, including private property. In such a law, implicit rights and freedoms of each person are respected, so as to feel free and free as normal. Life in the order of the law is much better than the atmosphere of previous life, where people competing against each other's interests without a planned build of common interests. In short, living in the order of law necessarily leads man to justice and decency.

Meanwhile, in Indonesia, the common goal (volonte generale) as a nation entity is included in the preamble of the 1945 Constitution which states that the goal of the Indonesian nation is to protect the entire Indonesian nation and the whole of Indonesia's blood sphere, promote the common prosperity, educate the nation, Implementing world order based on lasting peace and social justice.

Public law and private law meetings besides giving birth to problems, this is because the character of private law and the character of public law are contradictory. Though refers to the opinion of the philosophers both the principles of the law of covenants that are within 
the scope of private law and AAUPB are within the scope of public law both have a good purpose to create the regularity between legal subjects. Based on this background the authors are interested to examine the enactment of legal principles that have different characters in the government agreement, namely the correlation of the principle of contract law and the principle of public disclosure in government contracts. This paper is a legal research that uses a conceptual approach and a statute approach. Through this conceptual approach, this paper undertakes a study of the philosophical background of principles of contract law, and analyzes the possibility of applying the principle of openness as a representation of public law and the principle of contractual law simultaneously in government contracts or contracts.

\subsection{AGREEMENTS AND PRINCIPLES OF THE AGREEMENT}

Agreement or contract according to Agus Yudha Hernoko in his Law of Contract, Principle of Propositionality In Commercial Contract is a form of relationship of the parties to create an agreement to reconcile interests through bargaining process. Meanwhile, according to Subekti, the agreement is an event in which a person promises to others or where the two men promise to do one thing. The principle of contract law consists of,

1) The principle of freedom of ontract

2) The principle of pacta sun servanda

3) The principle of good faith 2

4) Proporsionality principle Scholars provide a different portion of attention to the principle of contract law, although in some ways there are similarities. The equation is the four principles that are considered as soko teacher contract law as mentioned above.

\subsection{GOOD GOVERNANCE AND AUPB (GENERAL PRINCIPLES OF GOOD GOVERNMENT) AS PUBLIC LEGAL PRINCIPLES}

Government as the subject of public law, bound by the principle of public law, which includes the General Principles of Good Governance and the principle of good governance. AAUPB becomes important and growing assimilated with the value of local wisdom in accordance with the needs of contemporary Indonesia, so the amount of
AAUPB is still flexible. However, in the written rule of law the Good Governance Principles have been mentioned in the explanation of article 53 paragraph (2) letter b law no.5 year 1986 jungto law no. 9 of 2004 on State Administrative Court.

For cases based on claims for damages by the authorities (government) through article 1365 Civil Code or law enforcement through the Administrative Court, the criteria in AAUPB can be used as a reference in addition to violations of the normative provisions of legislation.

1. The principle of legal certainty

Principles within a country of law prioritizing the basis of applicable legislation, propriety, and fairness in every policy.

\section{The orderly principle of state administration \\ Principles that form the basis of order, harmony and balance in the control of state administration}

\section{The principle of openness}

Principles that open themselves to the rights of the people to obtain true and honest, and nondiscriminatory information about the administration of the state with due regard to the protection of private rights, class and state secrets.

4. The principle of proportionality Principles that prioritize the balance between the rights and obligations of state officials.

5. The principle of professionalism Principles that prioritize expertise based on ethical codes and provisions of applicable laws and regulations

\section{Principles of accountability}

The decisive principle that every activity and the end result of the activities of the state organizer must be accountable to the public or the people as the highest sovereign of the state in accordance with the provisions of applicable laws and regulations.

As has been said that AAUPB in the Law Administration Sciences in its implementation is used to assess or test the actions of government executed its officials. 3

$\begin{array}{llr}\text { 2.3. LEGAL PRINCIPLES } & \text { OF } \\ \text { AGREEMENT AND AAUPB } & \text { IN } \\ \text { GOVERMENT AGREEMENT } & \end{array}$


The principle of contract law is the legal principle applicable when the government is party to an agreement. The Government acts as a party to the agreement in order to meet the public's needs. With the nature of the hybrid at the same time also apply the principle that should bind the subject of public law that is AAUPB principle.

The hybrid nature of the agreement of the government led to the theory of P de Han on the division of government legal action that divided the legal actions of the government into two legal actions, namely private legal action and public legal action explicitly become less relevant. In fact, the private legal action of the government which is subject to the civil law regime remains inherent in the nature of public law, the nature of public law that is still attached to government actions in the field of civilization such as the need for a basis of legality and authority. The customary act of private law based on the autonomy of the parties does not take place in government action, because the government in exercising its authority is bound to a series of rules as legal subjects representing the public.

The Government as a party to an agreement shall be subject to the principles of contract law. Principles of contract law include the principle of freedom of contract, the principle of consensualism, the principle of pacta sun servanda, the principle of good. In the principle of freedom of contract entails an agreement to pay attention to:

a. Legal requirements of the contract,

b. To achieve the objectives of the parties, the contract or agreement must have causa,

c. It does not contain a false causa or is prohibited by law,

d. Must be done in good faith.

As meant in the meaning of the principle both in the law of agreement is to fulfill decency and fairness. Government as the subject of public law representing the public in running the administration. Government runs government subject to AAUPB. So in doing the engagement as a party to an agreement, the government subject to AAUPB is a propriety.

Meanwhile, according to the principle of consensualism of the treaty is considered not to reflect the agreement, if in it there is a defect of the will (wilsgebreke) that affect the arising of the agreement. In BW defects of the will include 3 (three) things, ie: 4

Dwaling

b) Bedrog

c) Dwang

The submission of the government to the legality of the authority in binding itself as a party to the agreement can not be interpreted that the agreement was born under pressure. Because the legislation regulation is Volunte Generale (community agreement). Volunte generale or regulation can not be viewed as coercion because the birth process is a mutually agreed product.

Thus the principle of consensualism as enshrined in article $1320 \mathrm{BW}$ point 1 (of agreement or toestemming), which states that the treaty has been born fairly by agreement, should not be defined merely as grammatically defined. So the understanding of the principle of consensualism that emphasizes the existence of the word "agree" is departed from the understanding that who is dealing with the contract is a person who upholds the commitment and responsibility in the traffic law.5

\section{CONCLUCION}

Government as a predicate subject of public law can conduct private law acts and also perform public legal acts. Government as subject of public law is bound to General Principles of Good Governance. The government is also bound by the principles of contractual law when the government engages in engagement as a party to an agreement. The principles of contract law and the Good Governance Principles apply concurrently harmoniously and proportionately. So there is no contradiction in the validity of law between the principles of contract law and the principle of public disclosure as the implementation of AAUPB principles.

The existence of law is create order and harmony of human life. Government as a predicate subject of public law can conduct private law acts and also perform public legal acts. Government as subject of public law is bound to the principles of good governace and Good Governance General Principles. The government is also bound by the principlesof contractual law when the government engages in 
engagement as a party to an agreement. The principles of contract law, the principles of good governance, and the Good Governance Principles apply of contractual law when the government engages in engagement as a party to an agreement. The principles of contract law, the principles of good governance, and the Good Governance Principles apply concurrently harmoniously and proportionately. So there is no contradiction in the validity of law between the principles of civil law and the principle of public disclosure as the implementation of the principles of good governance.

\section{REFERENCES}

[1] Indroharto, Perbuatan Pemerintah Menurut Hukum Publik dan Hukum Perdata, Lembaga Penelitian dan Pengembangan Hukum Administrasi Negara Bogor, Jakarta, 1995, hal. 2

[2] Ibid.

[3] Ibid., hal. 3-4.

[4] Ibid., hal.5.

[5] Ibid., hal.72-73.

[6] Ibid., hal.79.

[7] Ibid., hal.80.

[8] Ibid.

[9] Ibid., hal.15

[10] Ibid., hal.19.

[11] Prasetyo, Dilema BUMN, Benturan Penerapan Business Judgement Rule dalam Keputusan Bisnis Direksi, Rayyana Komunikasindo, Jakarta, 2014, hal. 101.

[12] Ibid., hal.133.

[13] Agus Yuda Hernoko, Hukum Perjanjian: Asas Proposionalitas Dalam Kontrak Komersial, LaksBang Mediatama, Yogyakarta, 2008. hal. 1.

[14] Sogar Simamora, Hukum Kontrak: Kontrak Pengadaan Barang dan Jasa Pemerintah di Indonesia, Laksbang Justitia, Surabaya, 2011. hal.24.

[15] ibid., hal.23.

[16] Agus Yuda Hernoko, Op. Cit.,hal. 13.

[17] Ibid., hal. 92.

[18] ibid., hal.88.

[19] ibid., hal. 93.

[20] ibid., hal. 95.

[21] Ibid., hal. 97-98

[22] Ibid., hal. 107.

[23] Ibid.

[24] Ibid., hal.110.

[25] Sogar, Op. Cit., hal.30.
[26] Ibid., hal.33.

[27] Ibid., hal. 116.

[28] Ibid., hal. 124.

[29] Ibid., hal. 125.

[30] Ibid., hal. 87.

[31] Phipilus M. Hadjon, Pengantar Hukum Administrasi Indonesia, Gajah Mada University Press, Yogyakarta, Cet-8,2002, hal. 45.

[32] Ibid., hal.39.

[33] Philipus M. Hadjon, Hukum Administrasi Sebagai Instrument Hukum Untuk Mewujudkan Good Governance, dalam buku: Hukum Administrasi dan Good Governance, Universitas Trisakti, Jakarta, 2010, hal. 9.

[34] Paulus Effendie Lotulung, Tata

Kepemimpinan Yang Baik (good governance) Dalam korelasinya Dengan Hukum Administrasi, dalam buku: Hukum Administrasi dan Good Governance, Universitas Trisakti, Jakarta, 2010, hal. 37.

[35] Ibid,. hal.38-39.

[36] Ibid., hal.49.

[37] Ibid., hal.60.

[38] Ibid., hal. 107.

[39] Ibid.

[40] Agus Yuda Hernoko, Op Cit., hal.89.

[41] Paulus Effendie Lotulung, Op.Cit., hal.45.

[42] Muin Fahmal, Peran Asas-Asas Pemerintahan Yang Layak Dalam Mewujudkan Pemerintahan Yang Bersih, Kreasi Total Media, Yogyakarta, 2006.hal.96.

[43]Bryan A. Garner (ed), Black Law Dictionary, Tenth Edition, Thomson Reuters, St. Paul , USA,2014,hal.1729.

[44] Pilipus. M. Hadjon, Op.Cit.,hal.283. 